\title{
Effects of antioxidant supplementation on oxidative stress balance in young footballers- a randomized double-blind trial
}

\section{Błażej Stankiewicz}

Uniwersytet Kazimierza Wielkiego

\section{Mirosława Cieślicka}

Collegium Medicum in Bydgosz

\section{Sławomir Kujawski}

Uniwersytet Mikolaja Kopernika Collegium Medicum

\section{Elżbieta Piskorska}

Uniwersytet Mikolaja Kopernika Collegium Medicum

\section{Tomasz Kowalik}

Uniwersytet Kazimierza Wielkiego

\section{Justyna Korycka}

Uniwersytet Zielonogorski

Anna Skarpańska - Stejnborn ( $\nabla$ ankass@poczta.onet.pl )

Faculty of Physical Culture in Gorzów Wlkp. https://orcid.org/0000-0002-7795-3550

\section{Research article}

Keywords: total antioxidant capacity, radical oxygen species, exercise, diet supplement, football players

Posted Date: February 9th, 2021

DOI: https://doi.org/10.21203/rs.3.rs-36705/v2

License: (1) This work is licensed under a Creative Commons Attribution 4.0 International License. Read Full License

Version of Record: A version of this preprint was published at Journal of the International Society of Sports Nutrition on June 7th, 2021. See the published version at https://doi.org/10.1186/s12970-021-00447-z. 


\section{Abstract}

Background: The intensive physical exercise in which athletes take part in competitive sports can negatively affect the prooxidative-antioxidant balance. The use of compounds with high antioxidant potential, which certainly should include chokeberry, can prevent these adverse changes.

Methods: The study was conducted as a double blinded randomized trial on a group of football players (mean age=15.8), who underwent 7 weeks of supplementation with $200 \mathrm{ml}$ chokeberry juice per day. The players were randomly assigned to the experimental (supplemented, FP-S; $n=12$ ) and control (placebo, FB-C; $n=8$ ) groups. Before and after the supplementation period, participants performed an beep test. Venous blood was taken for serum isolation before, immediately after, $3 \mathrm{~h}, 24 \mathrm{~h}$ after the test Level of thiobarbituric acid reactive products (TBARS), hydroxy-2'-deoxyguanosine (8-OHdG), total antioxidant capacity (TAC), iron (Fe), hepcidin, ferritin, myoglobin, albumin and morphological parameters (RBC, HGB, HCT, MCV, MCH, MCHC and lactic acid) were measured.

Results: There were no significant impact of the supplementation intervention in response to the physical exercise test in the studied groups.. The post-hoc test showed no effect of chokeberry juice supply on any of the morphological, biochemical or performance parameters analysed.

Conclusions: The supplementation of Chokeberry juice shows no effects on measured parameters in studied populations. It may indicate Such results may indicate insufficient antioxidant capacity of the supplemented juice.

\section{Background}

Increased metabolism during physical exercise is accompanied by increased generation of reactive oxygen species, which may also cause disorders in the functioning of the immune system [1,2]. This applies primarily to high intensity and long lasting exercises. The mechanism of this process is not fully understood [3]. It is believed that excessive production of free oxygen radicals leads to many changes in body metabolism [4]. Observed intensive increase of oxygen radicals production leads to increase of erythrocytes damage, as a consequence of lipid peroxidation, and increasing sensitivity to degradation [5].

As a result of increased haemolysis, there is a significant increase in redox-active free iron concentration in blood serum [6].

Circulating free iron may be toxic and destructive for the cell components and body system fluids. Under conditions of oxidative stress, activation of the immune system and inflammation are also observed, which is an early defence response of the body. Probably in this way, oxidative stress is 'sustained' also during post-workout restitution [7]. Peaks of alternations of oxidative stress markers in blood after physical exercise bout based on concentric and eccentric contractions were observed between 0 and $4 \mathrm{~h}$ and 48-96 $\mathrm{h}$ after exercise bout, respectively [8,9]. The increase in ionized iron concentration in the blood serum, can contribute both to the intensification of free radical reactions on the one hand [10], and to weakening of the immune system on the other, thereby increasing susceptibility to infection $[11,12,13]$. Acute post-exercise depression of the immune system may result not only in increased frequency of infections in competitors, but also a higher percentage of cases (especially for upper respiratory tract diseases - URTI) and a much longer duration of URTI. Furthermore in many situations depression of immune system may effect higher possibility of injuries and depression of tissue regeneration [14].

Chokeberry contains a wide range of biologically active compounds, including polyphenols such as anthocyanin, flavonoids and phenolic acids $[15,16]$. Analysis of literature data indicates that compounds contained in chokeberry can have a positive effect on immune system and oxidative balance [17]. Particular importance is attributed to anthocyanins, in which chokeberry fruit is rich [18]. The advantage of these compounds is their comprehensive impact on both the immune system $[19,20]$ and reduction of oxidative stress, including the ability to chelate iron ions [21]. Anthocyanin supplementation might lead to reduced post-exercise muscle soreness [22] and improvement of performance parameters [23].

Page 2/19 
Analysis of the results available in the scientific databases conducted on athletes, as well as the results of numerous scientific reports based on research conducted on non-training people and animals, leads to the conclusion that the endogenous defence of an organism subjected to intense exercise load is insufficient [24]. It seems that preparations rich in anthocyanins may be an important factor in alleviating the adverse effects of extreme exercise loads. Thus, it seems advisable to introduce to the diet of competitors plants rich in anthocyanin's, which not only show the ability to form stable complexes with transition metals, but also increase the body's antioxidant potential. Such supplementation can both reduce oxidative stress, significantly reducing post-exercise inflammatory processes, and contribute to an increase in ergogenic potential [24].

The aim of the study was to analyse the effect of 7-week supplementation with chokeberry juice on the parameters of prooxidative-antioxidant balance and selected iron level parameters in professional young footballers during the football season comparing to placebo group in randomized double-blind trial.

\section{Methods}

\section{Participants}

The study was set as a double blinded randomised controlled trial with parallel groups. Participants were screened for inclusion/exclusion criteria by laboratory assistants. Twenty young male semi-professional footballers ( $15.8 \pm 0.7$ years old) from the MUKS Zawisza Bydgoszcz club participating in the Central Junior League competitions took part in the study. The subjects were randomly assigned to the supplemented $(n=12)$, or to the placebo group $(n=8)$. Each of the population was similar in terms of anthropometric data and the position on the football field (Table 1 ). Basic data regarding the study group are included in Table 1. Football players receiving chokeberry juice and a placebo implemented a uniform training load scheme. Training loads of the whole experimental time (microcycle) are shown in Table 2. Summary of load time intensity from the beginning of the season till the end of experiment are shown in Table 3.

All subjects were informed about the purpose of the research and the procedures used, and voluntarily agreed to participate in the experiment. The research was conducted according to the Declaration of Helsinki and after the positive opinion from the local Bioethics Committee at Collegium Medicum in Bydgoszcz (consent No. KB 382/2017). All players were assigned according to inclusion/exclusion criteria's and were asked not to use any other substances (vitamins, ergogenic supplements, herbal extracts, caffeine, theine etc.) two weeks before and during whole experiment. Week before the test and during whole experiment participants were adopted to similar eating habits and were asked to eat balanced meals calculated on the basis of the daily energy requirements in relation to age and physical activity. A substance that could interfere with the obtained test results and containing large amounts of anthocyanins, phytosterols and antioxidants were excluded from the meals. All meals were prepared according to the guidelines of a professional sports nutrition by sport nutritionist as recommended by the Polish Football Association [25].

\section{Experiment/supplementation}

The participants were randomly divided into two groups: supplemented $(\mathrm{N}=12)$, which received $200 \mathrm{ml}$ of chokeberry juice (100 $\mathrm{ml}$ twice a day in the morning and evening) for 7 weeks, and control $(n=8)$ which received a placebo at the same time according to guidelines [17]. The research protocol scheme is presented in Figure 1.

Figure 1. Research protocol. p.e.- physical exercise test

\section{Physical Exercise Program}

During the whole experimental period, all subjects retained their regular physical exercise program. Physical exercise programme was planned by the main coach of a team, the same for both groups in the above study. The training program microcycle presented in Table 2 is a uniform pattern of the tasks performed during the game season during which the 
research was conducted, and the intensity level of a given training unit is expressed using a scale from 1-10 (training loads scale).

\section{Supplementation}

The anthocyanin content was $165.3 \mathrm{mg} / 100 \mathrm{ml}$ of juice. Analysis of anthocyanin pigment contents were performed by HPLC according to Oszmański and Sapis [26]. Determination of anthocyanins was performed using the LC Agilent Technologies 1200 Rapid Resolution (Waldbronn, Germany) system equipped with a UV-Vis detector (DAD 1260,Waldbronn, Germany) and Zorbax, SB-C18 column (4.6 x $150 \mathrm{~mm}, 5 \mu \mathrm{m})$ (Agilent, Wilmington, USA). Separation was performed in a reverse phase system using gradient elution. Chromatographic conditions were as follows: injection volume, $20 \mu \mathrm{m}$; flow rate, $1.0 \mathrm{~mL} / \mathrm{min}$; solvent $A, 10 \%$ formic acid in water (v/v); solvent $B, 10 \%$ formic acid, $30 \%$ acetonitrile, $60 \%$ water (v/v/v) (gradient conditions: 0-8 min 20-40\% B, 8-15 min. 40-50\% B, 15-16 min 50-100\% B, 16-20 min 100\% B isocraticly, 20-23 min 100-20\% B). Chromatographic data was acquired from 400 to $600 \mathrm{~nm}$ and integrated at $520 \mathrm{~nm}$ for anthocyanins. Results are expressed as cyanidin-3-0-glucoside (external standard) (LGC Standards, UK) (mg/100 g or \%). Cyanidin-3-0-glucoside was dissolved in water. The chokeberry juice was diluted 10 times in redistilled water and filtered through $0.45 \mu \mathrm{m}$ filters for HPLC analysis.

Subjects in the control group were given the placebo containing $6.6 \%$ solution of betaine $[(\mathrm{CH} 3+) 3 \mathrm{~N}+\cdot \mathrm{CH} 2 \mathrm{COO}-]$ and $1 \%$ solution of citric acid. The placebo was identical to chokeberry juice in appearance and taste and were given in sintered glass bottles $200 \mathrm{ml}$ with a numerical signature. Participant position or volume of competition play (starters vs. non-starters) was not considered in the randomization. Both the chokeberry juice and placebo were produced by MLB Biotrade Sp. Z o.o., Poland (Poznan, Greater Poland, Poland). Players and researchers were not aware of group assignment. The players participating in the study were informed during the experiment not to take any additional supplements or medications. The label codes were decoded after the test

\section{Chokeberry juice antioxidant test}

The antioxidant capacity of chokeberry juice was determined using the DPPH and ABTS methods. , which amounted to 8.83 and $7.62 \mathrm{mg} / \mathrm{ml}$, respectively (tests were carried out by the Lubuskie Centre for Innovation and Agricultural Implementation of the University of Zielona Góra). Antiradical activity assays 2,20-azinobis(3-ethylbenzthiazoline-6-sulfonic acid) (ABTS), 2,2-di-phenyl-1-picrylhydrazyl radical (DPPH), and other reagents were purchased from Sigma Aldrich (St. Louis, MO, USA).

\section{Physical Exercise Test Protocol}

Before and after 7 week supplementation period, all players performed the Maximal Multistage 20 m Shuttle Run Test [27]. V02max was calculated indirectly based on the results of the physical exercise test according to method provided in literature [28]. The test ('beep test') was carried out in a full-size sports hall with a classic surface. The tests took place from $9.30 \mathrm{am}$ to $10.30 \mathrm{am}$. Participants were asked to eat a light meal approximately 2 hours before starting the exercise test. The subjects were instructed not to consume alcohol, caffeine, theine or taurine on the test day. The physical exercise test took place on Tuesday instead of the planned training session. Then, supplementation began on Monday, which ended after 7 weeks on Sunday. After supplementation period, subjects underwent the next test on the following Tuesday, instead of the planned training session. During the test, the air temperature was $19.1^{\circ} \mathrm{C}$ and humidity was $51 \%$. All tested players were informed about the test procedures and additionally motivated by the trainer to make maximum effort.

\section{Material collection and examination}

Blood samples were taken for analysis at four time points at the beginning and at the end of the experiment (supplementation period). Before exercise, immediately after the end after 3 and 24 hours from the end of test. Blood for serum was collected from the ulnar vein into Sarstedt serum tubes - $9 \mathrm{ml}$ with coagulant. The obtained blood was 
centrifuged (3000 rpm/10min) and blood serum was portioned and samples were frozen in liquid nitrogen and stored at $-80^{\circ} \mathrm{C}$ until further analyses.

To determine morphological parameters (RBC, HGB, HCT, MCV, MCH, MCHC) venous blood was collected in to $5 \mathrm{ml}$ tubes with $\mathrm{EDTAK}_{2}$ anticoagulant. The morphological examinations were performed using flow cytometry on Sysmex XS-1000i apparatus (Kobe, Prefecture Hyōgo, Japan).

The iron ( $\mathrm{Fe}$ ) level was determined in plasma taken from lithium heparin and determined by in vitro IRON 2 test for the quantitative determination of iron in human serum and plasma in a Roche/Hitachi Cobas c. system using a Cobas c 501 analyser (Rotkreuz, Zug canton, Switzerland).

Lactic acid (LA) was measured in capillary blood collected from the earlobe before and immediately after the test. The measurement was made using a Dr. Lange Plus LP20 biochemical analyser (Dr. Lange, Berlin, Germany).

For detailed analysis of changes in iron management, total antioxidant levels and inflammatory cell response, the following tests were used: ferritin ELISA EIA-1872, IL-6 ELISA EIA-4640, myoglobin ELISA EIA-3955 and hepcidin 25 (bioactive) HS ELISA EIA-5782 from DRG International, Inc., USA; human (TBARS) ELISA kit (catalogue no.: 201-12-7298) and human (8OHdG) ELISA kit (catalogue no.: 201-12-1437) from Shanghai SunRed Biological Technology Co. Ltd.; human albumin ELISA kit from Assaypro LLC, St. Charles, MO, USA; and TAC Fast Track DM P-4100 from Omnignostica Forschungs GmbH, Austria. A Thermo Scientific Multiscan GO Microplate Spectrophotometer produced by Fisher Scientific Finland was used for the material examination.

\section{Statistical analysis}

Sample size calculation was done based on previous results on the effects of supplementation on TBARS in males [29], as the variable of primary interest in the above study, using a calculator available online [http://powerandsamplesize.com/Calculators/Compare-2-Means/2-Sample-1-Sided]. As in previous research [29], it was decided to increase the sample size in the intervention group by setting the sampling ration as 1.5 . Power was set to 0.8 , while the Type I error rate was $5 \%$. The calculated sample size in intervention group was $n=12$. The Shapiro-Wilk $W$ test and visual assessment of histograms were used to test the assumption of normality.

Two-factor ANOVA with group coefficient (supplemented group/placebo group) and time (before/after supplementation) was selected for the analysis of physical fitness variables using aligned rank transform for nonparametric factorial ANOVA with ARTool package for R [30]. The post-hoc test for differences of differences was done using the R package phia [31]. Partial eta-squared was calculated to assess effect size of interaction in two-way ANOVA. To assess dynamics of biochemical parameters in response to the physical exercise test, a linear mixed model fit by REML with $t$-tests using Satterthwaite's method was applied with the R statistical packages Ime4 and ImerTest. Subject factor was set as a random effect. Time (before vs just after vs $3 \mathrm{~h}$ after vs $24 \mathrm{~h}$ after physical exercise test in the case of biochemical parameters; and before vs $3 \mathrm{~h}$ after in the case of blood morphometry parameters), group (placebo vs supplemented) and intervention (before vs after physical exercise programme) were set as fixed effects. Interaction between fixed effects was calculated as well as the confidence interval (95\%) for estimating interaction. Mean value and standard deviation (SD) are reported and the alpha level was set to 0.05 .

\section{Results}

There was no significant interaction between time $\times$ group and V02max $(58.82 \mathrm{ml} / \mathrm{kg} / \mathrm{min}$ before vs 60.35 after in the juice group, $58.48 \mathrm{ml} / \mathrm{kg} / \mathrm{min}$ before vs 60.36 after in the placebo group) $(F=0.04, p=0.84$, partial eta-squared $=0.002)$. In addition, there was no significant interaction of time $\times$ group in the distance covered in the $20 \mathrm{~m}$ shuttle run test (before supplementation $2509.09 \mathrm{~m}$ - level 13, interval 8 vs $2623.64 \mathrm{~m}$ - level 13, interval 13 and after supplementation in the juice 
group $2482.22 \mathrm{~m}$ - level 13, interval 7 vs $262.22 \mathrm{~m}$ - level 13, interval 13 after in the placebo group; $F=0.02, p=0.9, p a r t i a l$ eta-squared $=0.001$ ).

Interaction between influence of intervention $x$ group exercise test in the case of albumin was noted $(p=0.03)$. However, Albumin level was not changed significantly under the influence of physical exercise test, intervention and group (Table 4a).

Hepcidin level was not changed significantly under the influence of physical exercise test, intervention and group (Table 4a). Interaction between intervention and group was found in the case of iron level $(p=0.0495)$. However, iron level was not changed significantly under the influence of physical exercise test, intervention and group (Table 4a).

Biochemical analysis of the remaining selected parameters of inflammation did not show a significant interaction in the supplemented or placebo groups (Table 4a).

TBARS, 8 OHdG levels were not changed significantly under the influence of physical exercise test, intervention and group as well as the rest pro-oxidative-antioxidant balance indicators (Table 4b).

No significant effect of the chokeberry supplementation period was observed the blood smear results (Table 5).

As Table 6 shows, no significant changes in body weight, BMI or adipose tissue were observed after supplementation in any of the groups.

\section{Discussion}

The physical exercise in which athletes take part in competitive sport may result in a disturbance of homeostasis of the body, which in turn leads to much worse sports performance, as well as a deterioration of health [32]. Analysis of the available literature indicates that the compounds contained in chokeberry have strong antioxidant activity [33]. In this respect, a key role is attributed to anthocyanins, which prevent the excessive formation of free radicals, namely superoxide, hydroxyl, nitrite and chlorine radicals [34,35]. The anti-radical activity of these compounds is increased by the number of hydroxyl groups on the B ring and the arylation of sugar residues with phenolic acids. As demonstrated in the studies of van Acker et al., anthocyanins have 100 times higher activity in nitric oxide radical $(\cdot \mathrm{NO})$ removal than the endogenous antioxidant glutathione [36]. Due to the presence of hydroxyl groups in the $\mathrm{C}$ ring, these compounds are able to chelate transition metal ions (e.g. iron and copper) [37]. Another important feature of anthocyanins from the point of view of health is their ability to inhibit lipid peroxidation [38], which can be of great importance in reducing haemolysis induced by intense physical exertion $[39,40]$.

The antioxidant potential of the chokeberry juice given to football players was measured using two methods, DPPH and ABTS, as $8.83 \mathrm{mg} / \mathrm{ml}$ and $7.62 \mathrm{mg} / \mathrm{ml}$, respectively (relative to the activity of the Trolox reference compound), which indicates that it was relatively low compared to the amount of these compounds in extracts and fresh fruit [41]. This can probably explain the lack of statistically significant differences in the above study

Petrovic et al. [29] used chokeberry juice (100ml/day) supplementation for 4 weeks in handball players. After the completed period of supplementation, it was demonstrated small changes in the lipid profile and reduced TBARS levels; however, these changes were observed only in men. Cikiriz et al. [42] used aronia extract in the amount of $30 \mathrm{ml} /$ day in a group of handball players. The study protocol does not provide information on the detailed composition of the supplement or its antioxidant potential. Before the supplementation, which lasted 12 weeks, after 6 and 12 weeks, the subjects performed maximal physical exercise on the treadmill. Authors of the study indicate that the beneficial changes, namely a decrease in TBARS level, an increase in hemoglobin, erythrocytes and HDL occurred after 6 weeks of supplementation. In our research, the chokeberry juice had no effect on the reduction of free radical damage measured with both TBARS and 8-OHdG levels (Table 4b). García-Flores et al. combined chokeberry extract with citrus juice (200 $\mathrm{ml}$ of drink was $95 \%$ fresh citrus juice and $5 \%$ chokeberry extract); this combination of ingredients significantly reduced post-exercise changes in the level of DNA 
damage markers measured in both the plasma and urine of triathlon riders [43]. The above changes were observed with the anthocyanin content in the juice amounting to $53.4 \mathrm{mg}$. In our own research, the amount of anthocyanins was four times higher and amounted to $230.6 \mathrm{mg}$. Thus, it is likely that a combination of polyphenols, more than the content of anthocyanin compounds, may play a key role in reducing DNA damage.

Analysis of the available literature indicates that the advantage of compounds derived from chokeberry is their comprehensive effect on both the immune system and reduction of oxidative stress, including the ability to chelate iron ions, which seems to be a key element not only for iron management. For this reason, we expected it to reduce markers of oxidative stress. However, the lower (statistically insignificant) average values of the tested markers of oxidative stress, obtained in the second test period (after supplementation), concerned both the supplemented and control groups, which may be a result of the players' adaptation to the applied exercise loads. Zügel et al. analysed the cumulative effect of training stress in highly qualified athletes practising rowing on the level of hepcidin and its impact on parameters related to iron management. They showed that the levels of hepcidin and ferritin as acute-phase proteins were a sensitive indicator of changes in training loads (increase in volume and intensity of exercise) [44]. In the above study, football players were subjected to the same training loads throughout the entire study period, which probably explains the lack of statistically significant differences in the levels of hepcidin and ferritin . In other studies conducted by the team of Villaño et al., the effect of physical exercise and supplementation with juice high in polyphenols (the juice also contained chokeberry extract) on the level of hepcidin was analysed in a group of triathletes of both sexes. The study did not show a significant impact of the supplement on hepcidin, while hepcidin level reduction was associated with adaptation of the players' bodies to the applied exercise loads [45].

In our study of footballers, the level of iron after $3 \mathrm{~h}$ of rest in the supplemented group decreased, while in the control group it increased, however these differences were not statistically significant. Similar changes in iron levels after supplementation with aronia (150 ml / day) were observed in a group of rowers in our previous study [46]. Research on cell lines shows that anthocyanins build into the outer part of the erythrocyte membrane. The location of anthocyanins in the hydrophilic part of the membrane is a cell's protective shield against, among others, free radicals, making them safe and effective antioxidants. Probably this fact may be explained by the decreased level of iron compared to the control group [47].

It can be assumed that the ability to chelate iron ions, through the active compounds contained in chokeberry [48], can also counteract damage to muscle fibres. However, changes in myoglobin level in the above study were not significant. Myoglobin is a marker of muscle fibre damage; in the group supplemented with chokeberry it showed a downward trend, while in the control group the level of this parameter increased.

In the inflammatory process, the role of anthocyanins can result from both the ability to sequestrate iron [49] and from their regulatory action on various components of the immune system involved in the development of inflammation [50].

Research conducted by Ohgami et al. on animal models has shown that chokeberry extract has a strong anti-inflammatory effect on endotoxin-induced uveitis in rats. The authors observed that the number of inflammatory cells, the protein concentration, and the levels of NO, pyrogenic prostaglandin E2 (PGE2) and TNF $a$ in the aqueous humour in the groups treated with aronia crude extract were significantly reduced, and effect size depends on the dose used [51]. For this reason, the standardization of chokeberry products for the presence of anthocyanin compounds, which play a key role in health protection, may be of great importance.

One of the potential limitations of the above study is the relatively small sample size $(n=12$ and $n=8$ in supplemented and placebo groups, respectively). Further studies should incorporate larger sample sizes and/or implement crossover design in examining effects of antioxidants effect in professional athletes. Participant position or volume of competition play (starters vs. non-starters) was not considered in the randomization. Therefore, further studies should take those characteristics during randomization process. Moreover, the above research did not include control of diet regime. Potential changes in the amount of fruit and/or vegetables consumption might interfere with intervention applied. In addition, 
subjects compliance were not controlled. Implementation of web-based app with constant reminders on time and dosage would be appropriate to potentially resolve this problem.

Summing up the research results presented above, it can be stated that the use of chokeberry products in the diet did not cause significant changes in response to physical exercise test in the indicators of inflammation and iron management, prooxidative-antioxidant balance and blood morphology. The reason could be both good adaptation of the examined players to their physical exercise, and the use of juice with low antioxidant capacity. Therefore, it seems reasonable to consider the use of chokeberry extracts standardized for the presence of anthocyanins. Another issue that should be explored is to understand the mechanisms of how and what compounds contained in chokeberry may be responsible for improving the parameters studied.

\section{Conclusions}

Chokeberry juice supplementation applied to footballers did not affect the changes observed in players under the influence of the applied stress test in the indicators of inflammation and iron management, pro-oxidative-antioxidant balance and blood morphology. Such results could be the result of both good adaptation of athletes to the applied exercise loads, and the insufficient antioxidant capacity of the chokeberry juice used. Due to the relatively small sample size in the above study, further studies should be conducted on larger samples and/or implementation of crossover design. Further research should consider the supply of chokeberry in a more concentrated form, e.g. a concentrate or lyophilizate, to compare chokeberry supplement types (e.g. juice, concentrate, mixtures) or various levels of antioxidant potential. Potentially, extremely intensive physical exercise could lead to excessive muscle damage, which could decrease training progress. Future research should examine chokeberry juice effects in possible mitigating effects of muscle damage and training progress improvement.

\section{Abbreviations}

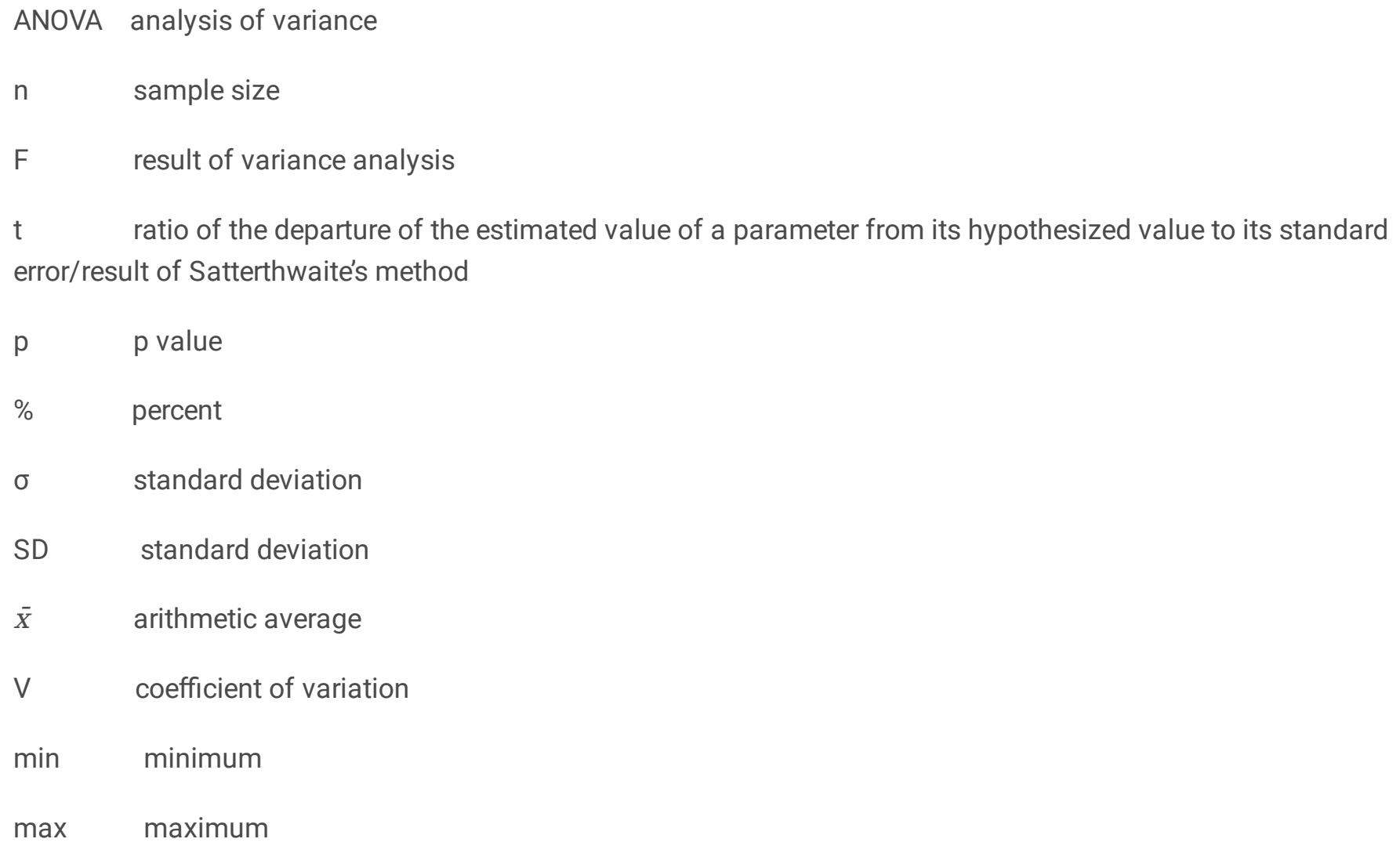




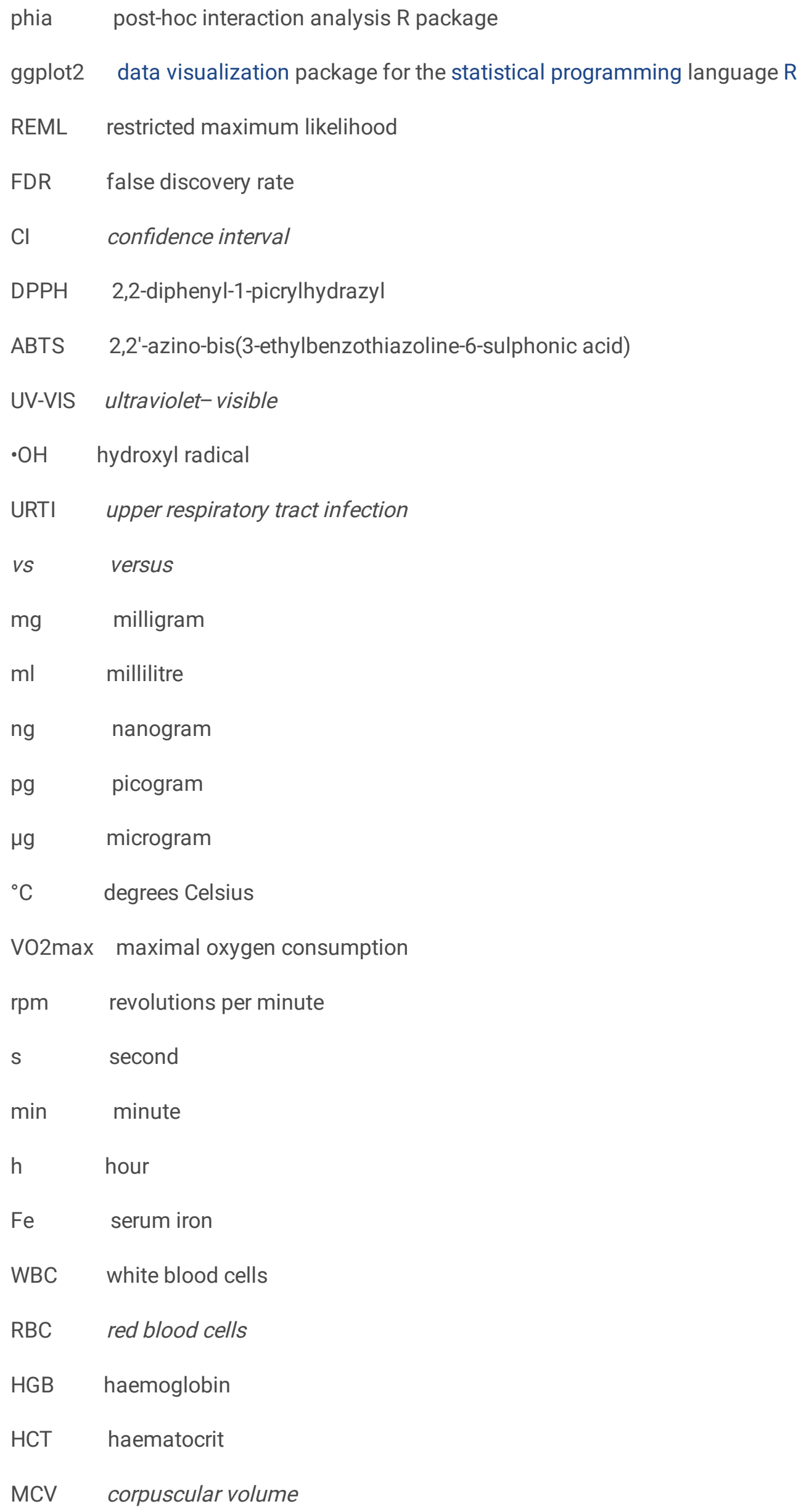




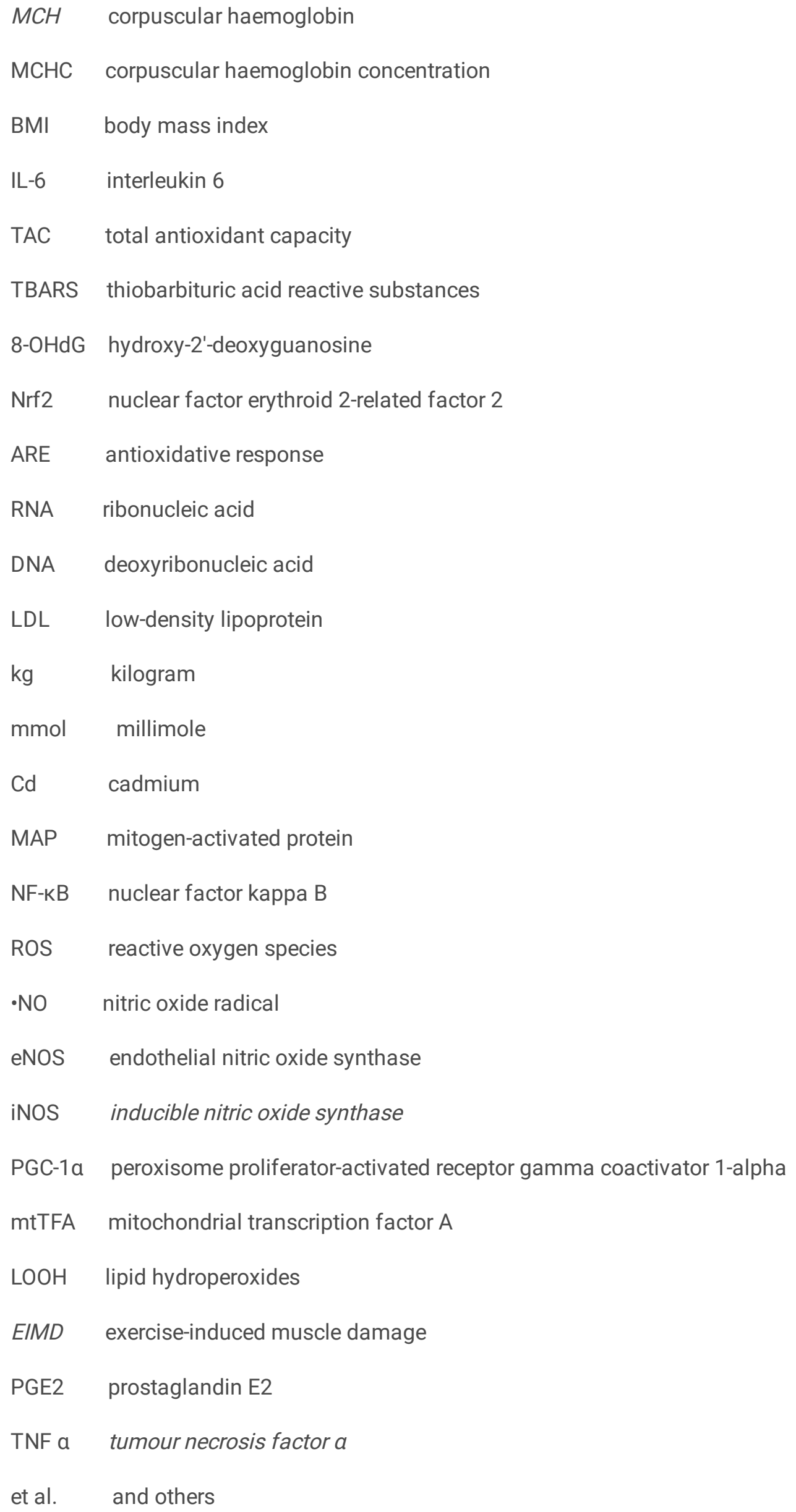




\section{Declarations}

\section{Ethical Approval and Consent to participate}

The research was conducted according to the Declaration of Helsinki and after the positive opinion from the local Bioethics Committee at Collegium Medicum in Bydgoszcz (consent No. KB 382/2017). All subjects were informed about the purpose of the research and the procedures used, and voluntarily agreed to participate in the experiment.

\section{Consent for publication}

Not applicable.

\section{Availability of supporting data}

Data and publication materials are available from the corresponding author on reasonable request

\section{Competing interests}

The authors declare no conflict of interest, financial or otherwise. The authors declare that the results of the study are presented clearly, honestly, and without fabrication, falsification or inappropriate data manipulation.

\section{Funding}

This study received no external funding.

\section{Author contributions}

BS, MC and ASS designed the study; BS, MC, EP and TK collected the data; BS, SK and ASS interpreted the results and drafted the manuscript. All authors approved the final version of the paper.

\section{Acknowledgements}

The authors would like to thank MUKS Zawisza Bydgoszcz coaches and players for participating in the project.

\section{Authors' information}

${ }^{1}$ Institute of Physical Education, Kazimierz Wielki University in Bydgoszcz, 2 Sportowa Str., 85-091 Bydgoszcz, Poland.

${ }^{2}$ Department of Physiology, Collegium Medicum in Bydgoszcz, Nicolaus Copernicus University in Toruń, 24 Karłowicza Str., 85-092 Bydgoszcz, Poland.

${ }^{3}$ Department of Hygiene, Epidemiology, Ergonomy and Postgraduate Education, Ludwik Rydygier Collegium Medicum in Bydgoszcz, Nicolaus Copernicus University in Toruń, 9 M. Curie Skłodowskiej Str., 85-094 Bydgoszcz, Poland.

${ }^{4}$ Department of Pathobiochemistry and Clinical Chemistry, Collegium Medicum in Bydgoszcz, Nicolaus Copernicus University in Toruń, 9 M. Curie Skłodowskiej Str., 85-094 Bydgoszcz, Poland.

${ }^{5}$ Institute of Food Sciences and Agrotechnics, University of Zielona Góra, Off-Campus Faculty in Sulechów, Pałac Kalsk Kalsk 67, 66-100 Sulechów, Poland. 
${ }^{6}$ Department of Morphological and Health Sciences, Faculty of Physical Culture in Gorzów Wielkopolski, 13 Estkowskiego Str., 66-400 Gorzów Wielkopolski, Poland.

\section{References}

[1] Hurst SM, Lyall KA, Hurst RD, Stevenson LM. Exercise-induced elevation in plasma oxidative generating capability augments the temporal inflammatory response stimulated by lipopolysaccharide. Eur J Appl Physiol. 2009;107(1):61-72.

[2] Woods JA, Pence BD. Physical activity, exercise, and the immune system: three lines of research that have driven the field. Kinesiol Rev. 2015;4(1):118-25.

[3] Sloth M, Sloth D, Overgaard K, Dalgas U. Effects of sprint interval training on VO2max and aerobic exercise performance: A systematic review and meta-analysis Scand J Med Sci Sports. 2013;23(6):e341-52.

[4] Rani V, Deep G, Singh RK, Palle K, Yadav UC. Oxidative stress and metabolic disorders: Pathogenesis and therapeutic strategies. Life Sci. 2016;148:183-93.

[5] Husain N, Mahmood R. Hexavalent chromium induces reactive oxygen species and impairs the antioxidant power of human erythrocytes and lymphocytes: Decreased metal reducing and free radical quenching ability of the cells. Toxicol Ind Health. 2017; 33(8):623-635.

[6] Tangudu N K, Alan B, Vinchi F, Wörle K, Lai D, Vettorazzi S, Leopold K, Vujić Spasić M. Scavenging Reactive Oxygen Species Production Normalizes Ferroportin Expression and Ameliorates Cellular and Systemic Iron Disbalances in Hemolytic Mouse Model. Antioxid Redox Signal. 2018;29(5):484-499.

[7] Valko M, Morris H, Cronin MTD. Metals, toxicity and oxidative stress. Curr Med Chem. 2005;12(10):1161-208.

[8] Michailidis Y, Jamurtas AZ, Nikolaidis MG, Fatouros IG, Koutedakis Y, Papassotiriou I, Kouretas D. Sampling time is crucial for measurement of aerobic exercise-induced oxidative stress. MSSE. 2007;39(7):1107-13.

[9] Nikolaidis MG, Paschalis V, Giakas G, Fatouros IG, Koutedakis YI, Kouretas D, Jamurtas AZ. Decreased blood oxidative stress after repeated muscle-damaging exercise. Med Sci Sports Exerc. 2007; 39(7):1080-9.

[10] Bresgen N, Eckl P. Oxidative stress and cell death: the role of iron. Free Radic Biol Med. 2018;124:558.

[11] Baltopoulos P. Exercise induced modulation of immune system functional capacity. Biol Exerc.2009;5(1):39-49.

[12] Walsh NP, Oliver SJ. Exercise, immune function and respiratory infection: an update on the influence of training and environmental stress. Immunol Cell Biol. 2016;94(2):132-9.

[13] Ward R, Crichton R, Taylor D, Corte L, Srai S, Dexter D. Iron and the immune system. J Neural Transm. 2011;118(3):315-28.

[14] Gleeson M, Pyne DB. Respiratory inflammation and infections in high-performance athletes. Immunol Cell Biol. 2016;94(2):124-31.

[15] Sikora J, Markowicz M. Biologically active compounds of fruit Aronia melanocarpa (Aronia melanocarpa Elliot). Oxid Med Cell Longev. 2014;2014:739721.

[16] Sueiro L, Yousef GG, Seigler D, De Mejia EG, Grace MH, Lila MA. Chemopreventive potential flavonoid extracts from plantation-bred and wild Aronia melanocarpa (black chokeberry) fruits. J Food Sci. 2006;71:480-8. 
[17] Borowska S, Brzóska MM. Chokeberries (Aronia melanocarpa) and their products as a possible means for the prevention and treatment of noncommunicable diseases and unfavorable health effects due to exposure to xenobiotics. Compr Rev Food Sci Food Saf. 2016;15(6):982-1017.

[18] Rodríguez W M, Esatbeyoglu T, Winterhalter P.. Phenolic Composition, Radical Scavenging Activity and an Approach for Authentication of Aronia melanocarpa Berries, Juice, and Pomace. Journal of Food Science. 2019;84(7), 1791-1798.

[19] Gajic D, Saksida T, Koprivica I, Vujicic M, Despotovic S, Savikin K, Jankovic T, Stojanovic I. Chokeberry (Aronia melanocarpa) fruit extract modulates immune response in vivo and in vitro. Journal of Functional Foods. 2020;66, 103836.

[20] Ho G T T, Bräunlich M, Austarheim I, Wangensteen H, Malterud K E, Slimestad, R, Barsett H . Immunomodulating Activity of Aronia melanocarpa Polyphenols. Int J Mol Sci. 2014; 15(7), 11626-11636.

[21] Jakovljevic V, Milic P, Bradic J, Jeremic J, Zivkovic V, Srejovic I, Nikolic Turnic T, Milosavljevic I, Jeremic N, Bolevich S, Labudovic Borovic M, Mitrovic M, Vucic V.. Standardized Aronia melanocarpa Extract as Novel Supplement against Metabolic Syndrome: A Rat Model. Int J Mol Sci. 2018;20(1).

[22] Cook MD, Willems MET. Dietary anthocyanins: a review of the exercise performance effects and related physiological responses. Int J Sport Nutr Exercise Metab. 2019;29(3):322-30.

[23] Pilaczynska-Szczesniak L, Skarpanska-Steinborn A, Deskur E, Basta P, M Horoszkiewicz-Hassan M. The influence of chokeberry juice supplementation on the reduction of oxidative stress resulting from an incremental rowing ergometer exercise. Int J Sport Nutr Exerc Metab. 2005; 15(1):48-58.

[24] McLeay Y, Stannard S, Houltham S, Starck C. Dietary thiols in exercise: oxidative stress defence, exercise performance, and adaptation. J. Int. Soc. Sports Nutr. 2017;Vol. 14, nr: 12.

[25] https://www.pzpn.pl/public/system/files/site_content/663/2781Manual\%20_Żywienie\%20młodych\%20piłkarzy.pdf.

[26] Oszmiansk J, Sapis JC. Anthocyanins in fruits of Aronia melanocarpa (chokeberry). J Food Sci. 1988;53(4), 12411242.

[27] Leger L, Mercier D, Gadoury C, Lambert J. The multistage 20 metre shuttle run test for aerobic fitness. J Sports Sci. 1988;6(2):93-101.

[28] Léger LA, Lambert J. A maximal multistage 20-meter Shuttle run test to predict V` O2max. Eur J Appl Physiol. 1982;49:1-12.

[29] Petrovic S, Arsic A, Glibetic M, Cikiriz N, Jakovljevic V, Vucic V. The effects of polyphenol-rich chokeberry juice on fatty acid profiles and lipid peroxidation of active handball players: results from a randomized, double-blind, placebocontrolled study Can J Physiol Pharmacol. 2016;94:1058-63.

[30] R Core Team. R: a language and environment for statistical computing. R Foundation for Statistical Computing. 2013, Vienna, Austria.

[31] De Rosario-Martinez H (2015). phia: post-hoc interaction analysis. R package version 0.2-1. https://CRAN.Rproject.org/package=phia.

[32] Smith LL. Cytokine hypothesis of overtraining: a physiological adaptation to excessive stress? Med Sci Sports Exerc. 2000;Feb;32(2):317-31. 
[33] Oszmiański J, Wojdylo A. Aronia melanocarpa phenolics and their antioxidant activity. Eur Food Res Technol. 2005;221, 809-813.

[34] Malinowska J, Oleszek W, Stochmal A, Olas B. The polyphenol-rich extracts from black chokeberry and grape seeds impair changes in the platelet adhesion and aggregation induced by a model of hyperhomocysteinemia. Eur J Nutr. 2013;52(3):1049-57.

[35] Tolić MT, Landeka Jurčević I, Panjkota Krbavčić I, Marković K, Vahčić N. Phenolic content, antioxidant capacity and quality of chokeberry (Aronia melanocarpa) products. Food Technol. Biotechnol. 2015;53(2):171-9.

[36] Van Acker SA, Tromp MN, Haenen GR, van der Vijgh WJ, Bast A. Flavonoids as scavengers of nitric oxide radical. Biochem Biophys Res Commun. 1995;214(3):755-9.

[37] Kokotkiewicz A, Jaremicz Z, Luczkiewicz M. Aronia plants: a review of traditional use, biological activities, and perspectives for modern medicine. J Med Food. 2010;13(2):255-69.

[38] Kim B, Ku CS, Pham TX, Park Y, Martin DA, Xie L, ... Bolling BW. Aronia melanocarpa (chokeberry) polyphenol-rich extract improves antioxidant function and reduces total plasma cholesterol in apolipoprotein E knockout mice. Nutr Res. 2013;33(5):406-13.

[39] Nishiie-Yano R, Hirayama S, Tamura M et al. Hemolysis Is Responsible for Elevation of Serum Iron Concentration After Regular Exercises in Judo Athletes. Biol Trace Elem Res. 2020;197, 63-69.

[40] Tedesco I, Moccia S, Volpe S, Alfieri G, Strollo D, Bilotto S, Spagnuolo C, Di Renzo M, Aquino RP, Russo GL. Red wine activates plasma membrane redox system in human erythrocytes. Free Radic Res. 2016;50(5), 557-569.

[41] Kapci B, Neradová E, Čížková H, Voldřich M, Rajchl A, Capanoglu E. Investigating the antioxidant potential of chokeberry (Aronia melanocarpa) products. Journal of Food \& Nutrition Research. 2013;52(4):219-29.

[42] Cikiriz N, Milosavljevic I, Jakovljevic B, Bolevich S, Jeremic J, Nikolic Turnic T, Mitrovic M, Srejovic I, Bolevich S, Jakovljevic V. The influences of chokeberry extract supplementation on redox status and body composition in handball players during competition phase. Can J Physiol Pharmacol. 2020; 8:1-6.

[43] García-Flores LA, Medina S, Cejuela-Anta R, Martínez-Sanz JM, Abellán Á, Genieser H-G, Ferreres F, Gil-Izquierdo Á. DNA catabolites in triathletes: effects of supplementation with an aronia-citrus juice (polyphenols-rich juice). Food Funct. 2016;7(4):2084-93.

[44] Zügel M, Treff G, Steinacker JM, Mayer B, Winkert K, Schumann U. Increased hepcidin levels during a period of high training load do not alter iron status in male elite junior rowers. Front Physiol. 2020;10:1577.

[45] Villaño D, Vilaplana C, Medina S, Algaba-Chueca F, Cejuela-Anta R, Martínez-Sanz JM, Ferreres F, Gil-Izquierdo A. Relationship between the ingestion of a polyphenol-rich drink, hepcidin hormone, and long-term training. Molecules. 2016;21(10):1333-45..

[46] Skarpańska-Stejnborn A, Basta P, Sadowska J, Pilaczyńska-Szcześniak L. Effect of supplementation with chokeberry juice on the inflammatory status and markers of iron metabolism in rowers. J Int Soc Sports Nutr. 2014; 11(1):48.

[47] Bonarska-Kujawa D, Pruchnik H, Kleszczyńska H. Interaction of selected anthocyanins with erythrocytes and liposome membranes. Cell Mol Biol Lett. 2012;17, 289-308.

[48] Hider RC, Liu ZD, Khodr HH. Metal chelation of polyphenols. Methods Enzymol. 2001;335:190-203. 
[49] Seeram NP, Nair MG. Inhibition of lipid peroxidation and structure-activity-related studies of the dietary constituents anthocyanins, anthocyanidins, and catechins. J Agric Food Chem. 2002;50(19):5308-12.

[50] Qin B, Anderson RA. An extract of chokeberry attenuates weight gain and modulates insulin, adipogenic and inflammatory signalling pathways in epididymal adipose tissue of rats fed a fructose-rich diet. Br J Nutr. 2012;108(4):581-7.

[51] Ohgami K, Ilieva I, Shiratori K, Koyama Y, Jin XH, Yoshida K, Kase S, Kitaichi N, Suzuki Y, Tanaka T, Ohno S. Antiinflammatory effects of aronia extract on rat endotoxin-induced uveitis. Invest Ophthalmol Vis Sci. 2005;46:275-81.

\section{Tables}

Table 1. Characteristics of the examined group

\begin{tabular}{|l|c|c|c|c|c|c|}
\hline $\mathrm{N}=20$ & $\begin{array}{c}\text { Age } \\
\text { [years] }\end{array}$ & $\begin{array}{c}\text { Years of training } \\
\text { [years] }\end{array}$ & $\begin{array}{c}\text { Height } \\
{[\mathrm{cm}]}\end{array}$ & $\begin{array}{c}\text { Weight } \\
{[\mathrm{kg}]}\end{array}$ & BMI [kg/m2] & $\begin{array}{c}\text { Body fat } \\
{[\%]}\end{array}$ \\
\hline $\bar{x}$ & 15.8 & 6.5 & 182.9 & 72.4 & 21.6 & 13.2 \\
\hline Min. & 15.2 & 5 & 168 & 61.7 & 18.8 & 10.6 \\
\hline Max. & 16.8 & 8 & 190 & 80.8 & 24.1 & 16.8 \\
\hline$\sigma$ & 0.7 & 0.8 & 5 & 5.6 & 1.3 & 1.8 \\
\hline $\mathrm{V}$ & 4 & 13.6 & 2.7 & 7.7 & 6.1 & 13.3 \\
\hline
\end{tabular}

$\bar{x}$ Legend: $\mathrm{N}$ - population, cm - centimetre, kg - kilogram, \% - percent, - arithmetic average, min. - minimum value, max. - maximum value, $\sigma$ - standard deviation, $V$ - coefficient of variation

Table 2. Training loads of the whole experimental time 


\begin{tabular}{|c|c|c|c|c|c|c|c|}
\hline Training & Monday & Tuesday & Wednesday & Thursday & Friday & Saturday & Sunday \\
\hline $\begin{array}{c}\text { Training } \\
\text { total } \\
\text { time }\end{array}$ & $45-60 \mathrm{~min}$ & $90 \mathrm{~min}$ & $90 \mathrm{~min}$ & $90 \mathrm{~min}$ & $45-60 \mathrm{~min}$ & $120 \mathrm{~min}$ & $30 \mathrm{~min}$ \\
\hline $\begin{array}{l}\text { Time of } \\
\text { a single } \\
\text { exercise }\end{array}$ & $\begin{array}{c}\text { Short } \\
2-4 \text { min }\end{array}$ & $\begin{array}{l}\text { Medium } \\
4-8 \text { min }\end{array}$ & $\begin{array}{c}\text { Long } \\
\text { 8-20 min }\end{array}$ & $\begin{array}{c}\text { Very short } \\
1-2 \text { min }\end{array}$ & $\begin{array}{c}\text { Short } \\
2-5 \mathrm{~min}\end{array}$ & $\begin{array}{c}\text { Long } \\
45 \text { min }\end{array}$ & $\begin{array}{c}\text { Long } \\
30 \mathrm{~min}\end{array}$ \\
\hline $\begin{array}{c}\text { Training } \\
\text { loads, } \\
\text { scale 1- } \\
10^{*}\end{array}$ & $1-2$ & $4-6$ & $5-8$ & $2-4$ & $3-5$ & $8-10$ & $1-2$ \\
\hline $\begin{array}{c}\text { Training } \\
\text { content }\end{array}$ & $\begin{array}{l}\text { Active } \\
\text { regeneration. } \\
\text { Large forms } \\
\text { of tactics } \\
\text { with } \\
\text { technique } \\
\text { breaks. }\end{array}$ & $\begin{array}{l}\text { Elements } \\
\text { of the } \\
\text { game in } \\
\text { attack } \\
\text { and } \\
\text { defence } \\
\text { in a } \\
\text { limited } \\
\text { field of } \\
\text { play. }\end{array}$ & $\begin{array}{l}\text { Maximum } \\
\text { intensity. } \\
\text { Endurance. } \\
\text { Small and } \\
\text { large } \\
\text { games. }\end{array}$ & \begin{tabular}{|l} 
Game speed \\
without much \\
resistance. \\
Defence \\
against \\
counterattack.
\end{tabular} & $\begin{array}{l}\text { Force- } \\
\text { speed } \\
\text { stimulation. } \\
\text { Tactical } \\
\text { games and } \\
\text { exercises } \\
\text { with an } \\
\text { accent of } \\
\text { speed. }\end{array}$ & $\begin{array}{l}\text { Control/ } \\
\text { championship } \\
\text { match. }\end{array}$ & $\begin{array}{l}\text { Active } \\
\text { regeneration } \\
\text { e.g.: } \\
\text { jogging, } \\
\text { walking, } \\
\text { swimming. }\end{array}$ \\
\hline
\end{tabular}

Legend: min - minutes, * - training loads scale where 1 means training at the lowest intensity and 10 means training at the highest intensity

Table 3. Summary of microcycle intensity (from the beginning of the season till the end of experiment)

\begin{tabular}{|l|c|c|}
\hline Work load characteristics & min. & $\%$ \\
\hline Aerobic & 2922 & 64,9 \\
\hline Mixed intensity & 1322 & 29,4 \\
\hline Anaerobic lactate acid dependent & 177 & 3,9 \\
\hline Anaerobic not lactic acid dependent & 143 & 3,2 \\
\hline Totality & 4499 & 100 \\
\hline
\end{tabular}

Table 4a. The impact of chokeberry supplementation on selected parameters of inflammation and iron management 


\begin{tabular}{|c|c|c|c|c|c|}
\hline & \multicolumn{2}{|c|}{ Supplemented group } & \multicolumn{2}{|c|}{ Placebo group } & \multirow[b]{2}{*}{$\begin{array}{l}\text { p-value interaction } \\
\text { intervention * effects of } \\
\text { physical exercise test } * \\
\text { group }\end{array}$} \\
\hline Parameters & $\begin{array}{c}\text { before } \\
\text { supplementation } \\
\text { Mean (SD) }\end{array}$ & \begin{tabular}{|c|} 
after \\
supplementation \\
Mean (SD)
\end{tabular} & $\begin{array}{c}\text { before } \\
\text { supplementation } \\
\text { Mean (SD) }\end{array}$ & \begin{tabular}{|c|} 
after \\
supplementation \\
Mean (SD)
\end{tabular} & \\
\hline \multicolumn{5}{|c|}{ Albumin $[\mu \mathrm{g} / \mathrm{ml}]$} & \\
\hline Before & $4.55(1.1)$ & $3.55(0.7)$ & $4.65(0.9)$ & $4.02(1.0)$ & \multirow{4}{*}{0.23} \\
\hline After & $4.85(0.6)$ & $3.79(0.6)$ & $5.34(1.7)$ & $3.69(0.6)$ & \\
\hline $3 \mathrm{~h}$ after & $4.46(0.8)$ & $3.31(0.5)$ & $5.57(1.8)$ & $3.63(0.8)$ & \\
\hline $24 \mathrm{~h}$ after & $4.33(1.2)$ & $3.73(0.9)$ & $5.15(1.8)$ & $3.23(0.4)$ & \\
\hline \multicolumn{5}{|c|}{ Myoglobin [ng/ml] } & \multirow{5}{*}{0.91} \\
\hline Before & $15.23(7.5)$ & $14.11(4.3)$ & $19.35(15.6)$ & $17.64(8.9)$ & \\
\hline After & $17.50(5.8)$ & $17.77(6.9)$ & $21.21(17.9)$ & $22.82(11.0)$ & \\
\hline $3 \mathrm{~h}$ after & $19.17(8.3)$ & $14.98(6.1)$ & $24.16(14.7)$ & $24.18(12.3)$ & \\
\hline $24 \mathrm{~h}$ after & 28.85 (13.6) & 17.60 (13.9) & $28.25(16.4)$ & 16.30 (7.5) & \\
\hline \multicolumn{5}{|c|}{ IL-6 [pg/ml] } & \multirow{5}{*}{0.99} \\
\hline Before & $47.44(13.1)$ & $48.42(18.8)$ & $42.80(7.0)$ & $44.51(4.2)$ & \\
\hline After & $49.97(12.7)$ & $54.25(24.5)$ & $43.83(2.3)$ & $49.11(4.8)$ & \\
\hline $3 \mathrm{~h}$ after & $51.35(23.1)$ & $47.47(10.4)$ & $45.75(11.9)$ & $45.33(4.0)$ & \\
\hline $24 \mathrm{~h}$ after & 46.84 (13.7) & 46.98 (10.8) & $43.97(5.0)$ & $45.18(3.9)$ & \\
\hline \multicolumn{5}{|c|}{ Hepcidin [ng/ml] } & \multirow{5}{*}{0.75} \\
\hline Before & $6.99(3.5)$ & $9.31(12.9)$ & $7.34(8.6)$ & $4.74(1.6)$ & \\
\hline After & $7.24(4.3)$ & $11.29(16.5)$ & $7.55(8.8)$ & $4.53(2.2)$ & \\
\hline $3 \mathrm{~h}$ after & $7.56(4.9)$ & $12.42(15.4)$ & $8.96(9.1)$ & $7.04(4.1)$ & \\
\hline $24 \mathrm{~h}$ after & $8.27(5.6)$ & $8.69(11.5)$ & $4.39(2.8)$ & $4.05(1.4)$ & \\
\hline \multicolumn{5}{|c|}{ Ferritin [ng/ml] } & \multirow{5}{*}{0.85} \\
\hline Before & $12.11(7.2)$ & $13.08(8.6)$ & $10.09(4.8)$ & $11.55(4.3)$ & \\
\hline After & $12.46(8.3)$ & $14.84(9.5)$ & $11.14(5.7)$ & $13.12(5.9)$ & \\
\hline $3 \mathrm{~h}$ after & $11.17(6.2)$ & $12.76(8.8)$ & $10.72(6.0)$ & $10.68(4.3)$ & \\
\hline $24 \mathrm{~h}$ after & $11.79(7.2)$ & $13.14(9.3)$ & $10.78(5.4)$ & $11.04(6.8)$ & \\
\hline \multicolumn{5}{|c|}{ Iron $[\mu \mathrm{g} / \mathrm{ml}]$} & \multirow{3}{*}{0.13} \\
\hline Before & $97.12(19.8)$ & $104.67(43.3)$ & $114.74(32.5)$ & $120.19(23.8)$ & \\
\hline $3 \mathrm{~h}$ after & $78.35(20.1)$ & $81.37(35.2)$ & $88.71(24.4)$ & $125(16.7)$ & \\
\hline
\end{tabular}

Legend: (SD) - standard deviation, $\mu \mathrm{g} / \mathrm{ml} \mathrm{-} \mathrm{micrograms/millilitre,} \mathrm{ng} / \mathrm{ml}$ - nanograms/millilitre, $\mathrm{pg} / \mathrm{ml}$ picograms/millilitre, before - before the test, after - after the test, $3 \mathrm{~h}$ after $-3 \mathrm{~h}$ after the test, $24 \mathrm{~h}$ after -24 $\mathrm{h}$ after the test

Table 4b. Influence of chokeberry supplementation on selected parameters of pro-oxidative-antioxidant balance 


\begin{tabular}{|c|c|c|c|c|c|}
\hline & \multicolumn{2}{|c|}{ Supplemented group } & \multicolumn{2}{|c|}{ Placebo group } & \multirow[b]{2}{*}{$\begin{array}{c}\text { p-value interaction } \\
\text { intervention * effects of } \\
\text { physical exercise test } * \\
\text { group }\end{array}$} \\
\hline Parameters & $\begin{array}{c}\text { before } \\
\text { supplementation } \\
\text { Mean (SD) }\end{array}$ & $\begin{array}{c}\text { after } \\
\text { supplementation } \\
\text { Mean (SD) }\end{array}$ & $\begin{array}{c}\text { before } \\
\text { supplementation } \\
\text { Mean (SD) }\end{array}$ & $\begin{array}{c}\text { after } \\
\text { supplementation } \\
\text { Mean (SD) }\end{array}$ & \\
\hline \multicolumn{6}{|c|}{ TAC [mmol/l] } \\
\hline Before & $1.36(0.3)$ & $1.94(0.7)$ & $1.03(0.3)$ & $1.76(0.5)$ & 0.49 \\
\hline After & $0.97(0.3)$ & $0.74(0.4)$ & $0.81(0.3)$ & $0.97(0.3)$ & \\
\hline $3 \mathrm{~h}$ after & $1.18(0.3)$ & $1.52(0.4)$ & $1.00(0.3)$ & $1.45(0.2)$ & \\
\hline $24 \mathrm{~h}$ after & $1.13(0.3)$ & $1.77(0.3)$ & $1.25(0.5)$ & $1.75(0.5)$ & \\
\hline \multicolumn{5}{|c|}{ TBARS [nmol/ml] } & \multirow{5}{*}{0.96} \\
\hline Before & $22.45(1.9)$ & $17.11(5.3)$ & $23.92(3.5)$ & $14.69(4.6)$ & \\
\hline After & $22.26(3.1)$ & $18.58(7.8)$ & $23.37(3.9)$ & $14.36(3.6)$ & \\
\hline $3 \mathrm{~h}$ after & $21.01(2.9)$ & $18.53(6.8)$ & $24.09(3.6)$ & $16.18(3.6)$ & \\
\hline $24 \mathrm{~h}$ after & $21.47(3.2)$ & $16.85(5.7)$ & $24.24(6.2)$ & $15.18(5.1)$ & \\
\hline \multicolumn{5}{|c|}{ 8-OHdG [ng/ml] } & \multirow{5}{*}{0.41} \\
\hline Before & $3.2(0.8)$ & $2.04(0.5)$ & $4.02(1.4)$ & $1.87(0.3)$ & \\
\hline After & $3.01(0.8)$ & $2.28(0.7)$ & $4.13(1.6)$ & $2.09(0.4)$ & \\
\hline $3 \mathrm{~h}$ after & $3.04(0.9)$ & $2.12(0.5)$ & $3.28(1.0)$ & $1.98(0.3)$ & \\
\hline $24 \mathrm{~h}$ after & $3.12(0.6)$ & $1.99(0.8)$ & $3.35(1.0)$ & $1.73(0.2)$ & \\
\hline
\end{tabular}

Legend: SD - standard deviation, mmol/l - millimoles/litre, $\mathrm{nmol} / \mathrm{ml}$ - nanomoles/millilitre, $\mathrm{ng} / \mathrm{ml}$ nanograms/millilitre, TBARS - thiobarbituric acid reactive substances, TAC - total antioxidant capacity, 8-OHdG - 8-oxo-2'-deoxyguanosine, before - before the test, after - after the test, $3 \mathrm{~h}$ after - $3 \mathrm{~h}$ after the test, $24 \mathrm{~h}$ after $-24 \mathrm{~h}$ after the test

Table 5. Effects of periods of antioxidant supplementation on blood morphology before and after physical exercise test

\begin{tabular}{|c|c|c|c|c|c|}
\hline & \multicolumn{2}{|c|}{ Supplemented group } & \multicolumn{2}{|c|}{ Placebo group } & \multirow[b]{2}{*}{$\begin{array}{c}\text { p-value interaction } \\
\text { intervention * effects of } \\
\text { physical exercise test } * \\
\text { group }\end{array}$} \\
\hline Parameters & $\begin{array}{c}\text { before } \\
\text { supplementation } \\
\text { Mean (SD) }\end{array}$ & $\begin{array}{c}\text { after } \\
\text { supplementation } \\
\text { Mean (SD) }\end{array}$ & $\begin{array}{c}\text { before } \\
\text { supplementation } \\
\text { Mean (SD) }\end{array}$ & $\begin{array}{c}\text { after } \\
\text { supplementation } \\
\text { Mean (SD) }\end{array}$ & \\
\hline \multicolumn{6}{|c|}{$\mathrm{WBC}[\mathrm{K} / \mathrm{\mu l}]$} \\
\hline before & $7.80(1.5)$ & $7.05(1.7)$ & $7.57(2.7)$ & $6.79(2.6)$ & \multirow[t]{2}{*}{0.78} \\
\hline $3 \mathrm{~h}$ after & $9.75(2.2)$ & $9.13(1.5)$ & $9.95(4.2)$ & $9.61(3.0)$ & \\
\hline \multicolumn{6}{|c|}{$\mathrm{RBC}\left[\mathrm{x} 10^{12} / 1\right]$} \\
\hline before & $4.89(0.2)$ & $5.07(0.3)$ & $4.75(0.2)$ & $4.98(0.3)$ & \multirow[t]{2}{*}{0.82} \\
\hline $3 \mathrm{~h}$ after & $4.86(0.2)$ & $4.87(0.3)$ & $4.68(0.3)$ & $4.77(0.2)$ & \\
\hline \multicolumn{6}{|c|}{$\mathrm{Hb}$ [g/dl] } \\
\hline before & $14.45(0.6)$ & $14.86(0.9)$ & $14.21(0.5)$ & $14.93(0.8)$ & \multirow[t]{2}{*}{0.86} \\
\hline $3 \mathrm{~h}$ after & $14.37(0.5)$ & $14.34(0.9)$ & $14.01(0.7)$ & $14.23(0.8)$ & \\
\hline \multicolumn{6}{|c|}{ Hct [\%] } \\
\hline before & $40.76(1.6)$ & $42.48(2.2)$ & $39.70(1.5)$ & $42.03(2.4)$ & \multirow[t]{2}{*}{0.79} \\
\hline $3 \mathrm{~h}$ after & $40.26(1.5)$ & $40.40(2.1)$ & $38.91(2.3)$ & $39.43(2.5)$ & \\
\hline \multicolumn{6}{|c|}{ Fe [pg/dl] } \\
\hline before & $97.12(19.8)$ & $104.67(43.3)$ & $114.74(32.5)$ & $120.19(23.8)$ & \multirow[t]{2}{*}{0.13} \\
\hline $3 \mathrm{~h}$ after & $78.35(20.1)$ & $81.37(35.2)$ & $88.71(24.4)$ & $125(16.7)$ & \\
\hline \multicolumn{6}{|c|}{ LA [mmol/l] } \\
\hline before & $1.45(0.3)$ & $1.60(0.3)$ & $1.56(0.3)$ & $1.48(0.2)$ & \multirow[t]{2}{*}{0.72} \\
\hline after & $9.85(2.4)$ & $10.58(1.8)$ & $9.62(1.9)$ & $10.56(1.8)$ & \\
\hline
\end{tabular}

Legend: SD - standard deviation, WBC - white blood cells, RBC - red blood cells, Hb - haemoglobin, Hct haematocrit, Fe - iron, LA - lactate acid 
Table 6. Body mass, body mass index and body fat level changes

\begin{tabular}{|c|c|c|c|c|c|}
\hline & \multicolumn{2}{|c|}{ Supplemented group } & \multicolumn{2}{|c|}{ Placebo group } & \\
\hline Parameters & $\begin{array}{c}\text { before } \\
\text { supplementation } \\
\text { Mean (SD) }\end{array}$ & $\begin{array}{c}\text { after } \\
\text { supplementation } \\
\text { Mean (SD) }\end{array}$ & $\begin{array}{c}\text { before } \\
\text { supplementation } \\
\text { Mean (SD) }\end{array}$ & $\begin{array}{c}\text { after } \\
\text { supplementation } \\
\text { Mean (SD) }\end{array}$ & $\begin{array}{l}\text { p-value intervention * } \\
\text { group interaction }\end{array}$ \\
\hline $\begin{array}{l}\text { Weight } \\
{[\mathrm{kg}]}\end{array}$ & $68.42(6.7)$ & $69.4(6.4)$ & $63.66(5.6)$ & $64.44(5.5)$ & 0.97 \\
\hline $\begin{array}{l}\mathrm{BMI} \\
{[\mathrm{kg} / \mathrm{m} 2]}\end{array}$ & $21.1(1.9)$ & $22.1(1.7)$ & $20.51(1.4)$ & $20.75(1.3)$ & 0.96 \\
\hline $\begin{array}{l}\text { Body fat } \\
{[\%]}\end{array}$ & $12.9(1.6)$ & $10.8(1.9)$ & $13.8(1.9)$ & $11.7(0.6)$ & 0.84 \\
\hline
\end{tabular}

Legend: SD - standard deviation, BMI - body mass index, body fat - percentage body fat 